\title{
Síndrome de Miller Fisher: relato de caso.
}

\author{
Joana Carolina Junqueira de Brum¹; Rômulo Gomes da Silveira1'; Barbára \\ Fontes Macedo1; Lucas Schaefer ${ }^{1}$; Rafaela Brambilla1; Diego Antônio \\ Fagundes ${ }^{2}$.
}

\section{RESUMO}

Introdução: a Síndrome de Miller Fischer (SMF), uma variante de Síndrome de Guillain Barré (SGB), possui diversas formas de apresentação clínica de difícil reconhecimento. SMF é uma desordem rara com incidência anual de um paciente por um milhão de habitantes, caracterizada pela tríade: oftalmoplegia, ataxia e arreflexia. A instituição terapêutica deve ser iniciada em até 2 semanas do início dos sintomas devido a possibilidade de progressão para sintomas neurológicos graves e necessidade de cuidados terapêuticos intensivos, evidenciando a extrema importância do reconhecimento precoce desta doença. Método: trata-se de um relato de caso de uma apresentação pouco comum de síndrome desmielinizante aguda pós-infecciosa. Resultados: 51 anos, feminina, obesa, hipertensa, diabetica e dislipidêmica procurou atendimento em hospital de emergência de Canoas/RS com queixa de visão turva, associada a parestesia nos quatro membros e incoordenação motora. Relatou episódio de rinossinusite há menos de 2 semanas. Ao exame neurológico apresentava estado mental preservado, disartria leve, pupilas midriáticas, não fotorreagentes bilateralmente, oftalmoplegia completa esquerda (III, IV e VI pares cranianos) e oftalmoparesia direita (III e VI pares cranianos), marcha atáxica e dismetria bilateral, força grau IV em membros inferiores, arreflexia patelar e aquiliana bilateralmente e reflexo cutâneo-plantar em flexão. Realizou ressonância magnética (RM) de crânio que não apresentou alterações significativas. Análise do líquor com presença de 1 célula e 62 proteínas. Realizou tratamento com imunoglobulina endovenosa por 5 dias apresentando melhora melhora clínica parcial.

Conclusões: SMF, uma polirradiculopatia monofásica inflamatória auto-imune, resultante da desmielinização dos nervos cranianos e periféricos, é a variante mais frequente de SGB, encontrada em 5\% dos casos. Além das alterações clínicas típicas

\footnotetext{
${ }^{1}$ Médico(a) residente do programa de pós-graduação em Medicina Interna da Universidade Luterana do Brasil. joanacjunqueira@gmail.com

${ }^{2}$ Medicina Interna e Neurologia no Hospital Universitário de Canoas. diegoafag@hotmail.com
} 
da tríade, deve-se valorizar a importância da anamnese (identificando quadro infeccioso prévio, o início e a evolução dos sintomas), a ausência de alterações na RM de crânio e a presença de dissociação cito-proteica com hiperproteinorraquia. Com o tratamento precoce, há evolução favorável na maioria dos casos, tendo resolução completa dos sintomas em 3-6 meses. Portanto o reconhecimento e tratamento precoce influenciam diretamente no sucesso terapêutico, na qualidade de vida do paciente e evita investigações adicionais desnecessárias.

Palavras Chave: Miller Fisher, Guillain Barré, doença desmielinizante aguda pós infecciosa.

\section{Miller Fisher syndrome: a case report.}

\section{Abstract}

Introduction: Miller Fisher syndrome (MFS), a variant of Guillain Barré Syndrome $(G B S)$, has several clinical forms difficult to identify. MFS is a rare disorder with an annual incidence of one patient by a million people, characterized by the triad ophthalmoplegia, ataxia and areflexia. The therapeutic institution should be initiated within 2 weeks of the onset of symptoms due to the possibility of progression to severe neurological symptoms and need for intensive therapeutic care, highlighting the extreme importance of early recognition of this disease. Method: This is a case report of an unusual presentation of post-infectious acute demyelinating syndrome. Results: 51, female, obese, hypertensive, diabetic and dyslipidemic sought care in hospital emergency Canoas / RS with blurred vision complaints, associated with paresthesia in four limbs and incoordination. Episode of rhinosinusitis reported for less than 2 weeks. Neurological examination revealed preserved mental status, mild dysarthria, mydriatic pupils, not fotorreagentes bilaterally, complete left ophthalmoplegia (III, IV and VI cranial nerves) and right ophthalmoparesis (III and VI cranial nerves), gait ataxia and bilateral dysmetry, strength grade IV in the lower limbs, areflexia and patellar aquiliana bilaterally and skin-plantar flexion reflex. Performed magnetic resonance imaging (MRI) of the skull showed no significant changes. Analysis of cerebrospinal fluid in the presence of 1 cell and 62 proteins. She underwent treatment with intravenous immunoglobulin for 5 days with improvement 
partial clinical improvement. Conclusions: MFS an inflammatory polyradiculopathy autoimmune single phase, resulting in demyelination of peripheral nerves and cranial is the most frequent variant of GBS found in 5\% of cases. In addition to the typical clinical changes of the triad, one should value the importance of anamnesis (identifying previous infectious condition, the onset and progression of symptoms), the absence of changes in brain MRI and the presence of cyto-protein dissociation with high level of protein concentration. With early treatment, there is a favorable evolution in most cases, with complete resolution of symptoms in 3-6 months. Therefore the recognition and early treatment directly influence the therapeutic success in the patient's quality of life and avoid unnecessary further investigation.

Keywords: Miller Fisher, Guillain-Barré syndrome, post-infectious acute demyelinating disease. 


\section{Referências}

ARÁNY, Z.; KOVÁCS, T.; SIPOS, I.; BERECZKI, D. Miller Fisher syndrome: Brief overview and update with a focus on electrophysiological findings. Eur J Neurol 2012;19:15-20.

PAPANIKOLAOU, T.; GRAY, C.; BOOTHMAN, B.; NAYLOR, G.; MARIATOS, G. Acute bilateral ophthalmoparesis with pupilary areflexical mydriasis in Miller-Fisher syndrome treated with intravenous immunoglobulin. J Ophthalmol 2010.

WAKERLEY, B.R.; UNCINI, A.; YUKI, N. \& THE GBS CLASSIFICATION GROUP. GuillainBarré and Miller Fisher syndromes-new diagnostic classification. Nature Reviews Neurology 2014;10:537-544.

WAKERLEY, B.R.; YUKI, N. Mimics and chameleons in Guillain-Barré and Miller Fisher syndromes. Pract Neurol. 2015; 2:90-9. 